\title{
Distinction, cohesion and the social networks of Australia's elite suburbs
}

Ilan Wiesel, School of Geography, Science Faculty, University of Melbourne

Email: ilan.wiesel@unimelb.edu.au Tel: +61-3-8344-7468 Address: 221 Bouverie St, Carlton VIC, 3052 AUSTRALIA

\section{Abstract}

Understanding the role of elite neighbourhoods in wider processes of rising inequality at national and global scales is an emerging agenda in urban studies. In this paper I focus on the role of the neighbourhood in the production of elite social networks, as a source of social capital. Focusing on three of Australia's most affluent neighbourhoods - Mosman (Sydney), Toorak (Melbourne) and Cottesloe (Perth) the study involved a mixed method approach, including a survey of over 1,000 residents, and follow up in depth interviews with forty-six of them. The paper presents descriptive quantitative characterisation of elite neighbourhood residents' social networks, using occupation as proxy for the social class positions of network members. Further qualitative analysis is presented to explain the role of neighbourhood institutions and everyday practices - including neighbourly relations, random encounters, and participation in schools and sports clubs - in the formation of elite social networks. The findings demonstrate that elite neighbourhoods should be understood as more than merely fortified playgrounds for conspicuous consumption, rather important sites of capital accumulation.

\section{Keywords}

Elites; Neighbourhood; Social networks; Social capital; Schools

\section{The socio-spatial dynamics of accumulation}

Recent years have seen a surge of attention to income and wealth inequalities, both globally and within states and cities, with historically unprecedented concentration of wealth in the hands of elites (Piketty et al., 2014; Credit Swiss, 2016; ABS, 2015). In urban geography, analysis has focused on the drivers of polarisation across 
metropolitan and neighbourhood scales. Much of this work concerns the neighbourhood effects compounding the disadvantage of cities' poorest citizens living in deprived neighbourhoods (Galster, 2012; van Ham et al., 2012). At the same time, there is a growing interest in the urban geographies of elites, and especially the substrata of the 'super-rich'. Some recent literature investigates the spatial concentration of elites in exclusive (often gated) urban neighbourhoods, and considers whether and how it enhances their privileges and advantage in relation to subordinate social strata (Pow, 2011; Atkinson, 2016; Holmqvist, 2017). This strand of literature investigates the role of such enclaves as "places in which transnational elites organise their administration, consumption, production, leisure, education, and housing" (Webster et al., 2002: 318). As noted by Frantz (2006: 74), the choice to live in fortified elite enclaves is both a statement about identity and status, and a strategy of gaining practical and material advantages.

For example, Pow's (2011) study of Sentosa Cove, a newly established super-rich gated community in Singapore, found that it allowed avoidance of difference, while at the same time conferring other financial and citizenship privileges (Pow, 2011, p. 388). Atkinson's (2016: 1302) analysis of the super-rich in London, found that this group of elites is 'able to use residential locational choices and choregraphed mobilities as strategies to avoid negative aspects of daily life in the city', including any sight of visible poverty, potential danger, or spaces of social and ethnic difference.

Holmqvist's (2017) argues that elite neighbourhoods - or "leader communities" - can facilitate a process of "consecration", whereby wealthy residents become "imbued with a certain aura... of grandness, nobility and majesty" (Holmqvist, 2017, p. 256-7). Focusing on the affluent neighbourhood of Djursholm in Stockholm, Holmqvist argues that the neighbourhood's aura elevates Djursholm's wealthy residents from "mere mortals into leaders" (p. 85). Drawing on Bourdieu's (1986) concept of cultural capital, Holmqvist argues that the process of consecration plays an important role in the reproduction of elites' distinction and domination.

Like Holmqvist (2017), in this paper I draw on Bourdieu's conceptual framework, however my focus is on the elite neighbourhood's role in the production of social rather 
than cultural capital. This addresses a gap in urban studies, where neighbourhood social capital research has focused primarily on deprived neighbourhoods. To address the question of elite neighbourhoods' role in the production of social capital, the mixedmethod empirical analysis presented here follows two trajectories. First, drawing on a survey of over 1,000 residents in three of Australia's most affluent neighbourhoods Mosman (Sydney), Toorak (Melbourne) and Cottesloe (Perth) - the survey characterises their social networks. Using the occupations of respondents' friends as proxy for their social class positions, this analysis demonstrates the high-powered nature of elite suburb residents' social networks. Second, as Bourdieu (1986: 52) points out, social capital is never a given, rather "the product of an endless effort at institution" through a set of practices. Thus, drawing on qualitative analysis of forty-six in-depth interviews with residents in these suburbs, the paper examines the role of neighbourhood institutions and everyday practices - including neighbourly relations, random encounters, and participation in schools and sports clubs - in the formation of both weak and strong ties within these neighbourhoods.

\section{Social capital and the neighbourhood}

Bourdieu (1986: 52) defined the distribution of economic, social and cultural capital as representing the "immanent structure of the social world, i.e., the set of constraints... determining the chances of success for practices". Economic capital is the chief of the three capitals in Bourdieu's theory, but social and cultural capitals play important roles in facilitating and concealing the monopoly over economic capital by closely-bounded elites, and the transfer of such monopoly from one generation of elites to the next. Social and cultural capitals fulfil this function most effectively when they take time to accumulate, for example through many years of education in elite schools (Kenway, 2017), or - as I argue here - many years of socialising in an elite neighbourhood.

In this paper I focus on social capital, which Bourdieu (1986: 47) defined as the sum "of social obligations ('connections'), which is convertible, in certain conditions, into economic capital":

Social capital is the aggregate of the actual or potential resources which are linked to possession of a durable network of more or less 
institutionalized relationships of mutual acquaintance and recognition - or in other words, to membership in a group -which provides each of its members with the backing of the collectively-owned capital, a 'credential' which entitles them to credit, in the various senses of the word (Bourdieu, 1986: 51),

Critics of Bourdieu's theory of capital point to his characterisation of social relations and cultural practices as being necessarily motivated by instrumental drivers (i.e. pursuit of status and access to resources), as opposed to affective motivations such as emotional attachment (Portes, 1998).

Putnam's (2000) influential work on social capital represented a significant departure from key elements in Bourdieu's theory. Putnam's approach is concerned with measuring social connectedness vested in communities in the form of formal and informal voluntary associations. The emphasis, thus, is on the "relational content" (Williams, 2007) of networks. For Putnam, social connectedness - networks characterised by relations of trust and reciprocity - is a social capital resource that can produce benefits in terms of children's welfare, neighbourhood safety, economic productivity, health, happiness and democracy. This contrasts with Bourdieu's (1986) emphasis on the "exchange content" (Williams, 2007) of such networks, including the status of members and the resources that are available to them. As commented by Gauntlett (2011: 2), while writers such as Putnam, "see social capital as a fundamentally heartwarming network of social connections... Bourdieu uses it to explain the cold realities of social inequality."

Social capital can be understood as a neighbourhood effect. The neighbourhood effects hypothesis has been defined as "the idea that living in deprived neighbourhoods has a negative effect on residents' life chances over and above the effect of their individual characteristics" (van Ham et al., 2012: 1). While most neighbourhood effects literature to date has focused on deprived neighbourhoods, the concept could also be applied in terms of positive effects of living in more privileged neighbourhoods. One potentially positive neighbourhood effect is the opportunity to accumulate social capital by building social networks in the neighbourhood. Indeed, Galster (2012: 25), defines social networks - "interpersonal 
communication of information and resources of various kinds transmitted through neighbours" - as one of several known social-interactive neighbourhood effect mechanisms. A large body of literature in urban studies concerns measurement of neighbourhood social capital effects and their consequences. This strand of literature has been overwhelmed by studies examining the physical and mental health effects of neighbourhood social capital (Ziersch et al., 2005). Other, smaller but substantive bodies of literature examine other social capital neighbourhood effects, for example on crime and safety (Lindstrom et al., 2003) and, disaster resilience (Aldrich, 2012).

Beyond scholarly literature, the concept of social capital - especially in its Putnaminspired interpretations - has been influential in policy development. The concept's allure in policy circles can be partly explained by its perception as an inexpensive "wonder drug to alleviate the impact of structural inequalities" (Jennings, 2007a: 90). This view of social capital has been criticised as a de-politicised behavioural discourse that depicts low-income people as deficient and thus responsible for their poverty, while overlooking structural explanations and solutions (Jennings, 2007b: $3)$.

High levels of social capital, when defined in terms of connectedness, are often depicted as a coping mechanism used by deprived communities in the face of more structural disadvantage. Elites have resources to sustain networks outside their neighbourhood or even country, thus their social capital is less dependent on the neighbourhood in which they live (Atkinson 2008). Furthermore, as a coping mechanism, social capital is considered less relevant to more affluent communities since they possess other material resources to buffer against misfortune (Hill et al., 2014: 66; Forrest and Kearns, 2001: 2130). This approach is inconsistent with Bourdieu's theorisation of social capital as a mechanism of differentiation or 'distinction', and thus a pillar of the social class structure itself rather than merely a coping mechanism.

Studies of urban neighbourhood social capital that follow Bourdieu's approach are fewer, perhaps in part because the spatiality of capital is under-developed in Bourdieu's work (Savage et al. 2005). Studies that do utilise Bourdieu's capitals tend to be more attentive to middle- and upper-class neighbourhoods (Butler, 2008; 
Holmqvist, 2017), and to cultural capital (and the related concepts of habitus and field) rather than social capital (Savage et al., 2005).

Despite the tensions between Bourdieu and Putnam's interpretations of social capital, some studies have applied a hybrid model integrating both (Butler, 2008; Israel and Frenkel, 2015). For example, in his analysis of London's gentrified neighbourhoods, Butler (2008) argued that gentrification had devastated the 'Putnam-style' bonding capital that characterised the working-class communities in these neighbourhoods, but saw the emergence of new forms of 'Bourdieu-style' social and cultural capitals that reproduced the advantage of incoming middle-class households. In this paper, I follow a similar hybrid model, using the concept of elite integration as a bridging concept, as elaborated in the following section.

\section{Elites and elite integration}

The term elites is closely related, but not synonymous with upper-class. Elites are defined as 'persons with power to affect organizational outcomes individually, regularly and seriously' (Higley, et al., 1979, 3). An upper-class position derives from property ownership, much of it inherited through family connections, and can only exist in a capitalist economy (Higley et al. 1979, p. 7). In contrast, elites can - and perhaps inevitably will - exist and occupy strategic positions of power and influence in any kind of economy or social structure, "whether these are capitalist, socialist or a mixture of both" (Higley et al. 1979. Pp.8-9).

Elite studies have long debated the question of whether the elite consists of a highly concentrated, cohesive network of overlapping elite circles, or whether multiple elite networks are fragmented across separate political, economic and cultural domains (Keister and Southgate, 2012: 132-6). Theories of elite integration or cohesion maintain that elites' domination depends on their capacity to overcome such fragmentation and resolve internal differences and conflict between different sub-groups or individual members of the elite (Higley et al., 1979: 265; Connell et al., 1986; Zweigenhaft and Domhoff, 2006). To achieve cohesion, the elite must build strong networks of interpersonal 
relationships, a sense of trust, solidarity, mutual access, shared outlooks and values, and sharing of information across diverse elite circles. When such cohesion is achieved, the elite can be understood as a 'ruling class':

Ruling class cohesion begins to be built well before its hereditary members reach adult life. They generally attend certain private schools, grow up in particular suburbs and participate in leisure activities that are the preserve of the rich. Later in life, the ruling class socialises at exclusive private clubs, in corporate boxes at the football, at prestigious cultural events and charity fundraisers. This shared social milieu helps create close contacts and shared social outlooks at least amongst a core of the ruling class. It provides informal opportunities to discuss matters of concern among wider circles of associates than is possible within individual corporations. (Pietsch, 2004: 26)

The concept of elite integration or cohesion, thus, points to the importance of social connectedness (described in terms that resemble Putnam) to wider, structural processes of social class stratification (described in terms that resemble Bourdieu). It allows understanding of social connectedness at the neighbourhood scale, not merely as a coping strategy for the disadvantaged, but also as a condition for the reproduction of elite privilege.

Such questions about social networks and cohesion are by no means unique to elite neighbourhoods. Similar questions about collective efficacy (Sampson, 2008) arise in relation to neighbourhoods of lower socioeconomic status. However, the collective efficacy of elites has implications that extend well beyond the boundaries of their own neighbourhoods, because of their domination of national and global economic, political and cultural institutions.

\section{Toorak, Cottesloe and Mosman}

The empirical element of my study focused on three of Australia's most affluent suburbs: Toorak (Melbourne), Mosman (Sydney) and Cottesloe (Perth) (Figure 1; Table 1). The term 'suburb' is commonly used in Australia with a similar meaning to 'neighbourhood', and is not necessarily indicative of distance to the city centre or a 
low-density urban form. The area and population of urban areas formally classified as 'state suburbs' vary substantially.

Figure 1: Australian Capital Cities

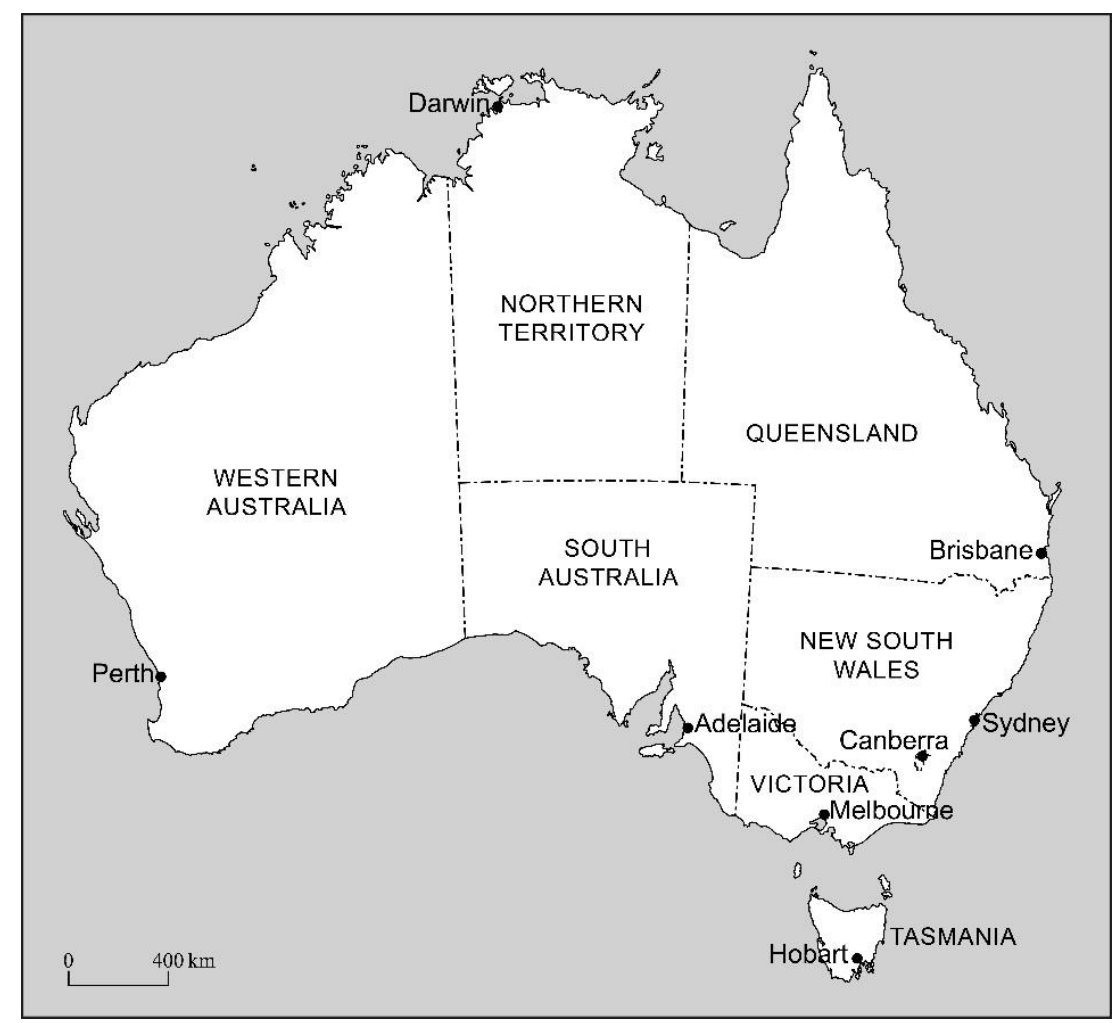

Credit: Chandra Jayasuria

Table 1: Population, income and house prices in Toorak, Mosman and Cottesloe

$\begin{array}{llll}\text { Population } & \text { Median } & \text { Median house } & \text { House price } \\ \text { (2011) } & \text { household } & \text { price (2016) } & \text { ranking in } \\ & \text { income } & & \text { respective city }\end{array}$

Accepted version of Wiesel, I. (2018). Distinction, cohesion and the social networks of Australia's elite suburbs. Urban Geography, 1-22.

https://www.tandfonline.com/doi/abs/10.1080/02723638.2018.1500250 


\begin{tabular}{lllll} 
Toorak & 12,871 & $\$ 1,977$ & $\$ 3,400,000$ & 1 st \\
\hline Mosman & 27,452 & $\$ 2,465$ & $\$ 3,290,000$ & 8 th \\
\hline Cottesloe & 7,398 & $\$ 2,494$ & $\$ 1,700,000$ & 3 rd \\
\hline Australia & $22,485,300$ & $\$ 1,216$ & $\$ 658,608$ & N.A.
\end{tabular}

Sources: ABS, 2011; Real Estate Australia, 2016a, 2016b, 2016c

Toorak is a state suburb in Melbourne, Victoria, with a population of 12,871 people recorded in the 2011 Census. Located on the south bank of the Yarra River, it is only $5 \mathrm{~km}$ from Melbourne Central Business District (CBD) (Figure 2). Established in the 1850s, Toorak has long sustained its status as the city's wealthiest suburb. An early study of Toorak undertaken by Campbell (1963) argued that the suburb "probably houses more millionaires than any area of comparable size in any part of the world" (Campbell, 1963: 36). Toorak properties are still the most expensive in Melbourne, with a median house price of $\$ 3,400,000$ (Real Estate Australia, 2016), leading by a substantial margin above any other Melbourne suburb. In 2014-15, postcode 3142 (centred around Toorak) ranked first in the state in terms of both its residents' income and their Capital Gains as recorded by the Australian Tax Office. Toorak residents' combined reported capital gains of over $\$ 730,000,000$ in 2014-15 was more than 45 times higher than the average for all postcodes nationally (Australian Tax Office, 2015).

Figure 2: Toorak and Greater Melbourne 


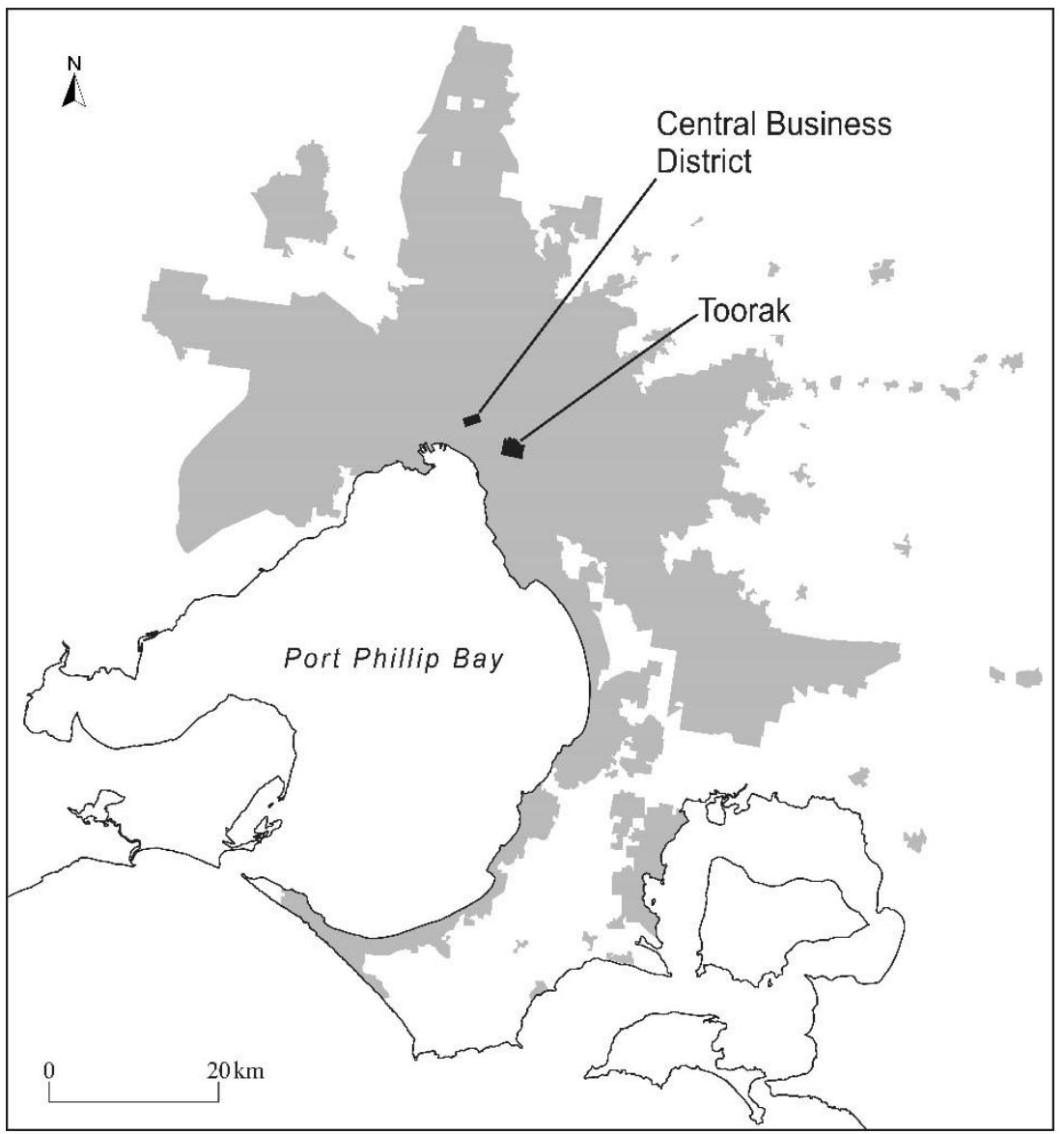

Credit: Chandra Jayasuria

Accepted version of Wiesel, I. (2018). Distinction, cohesion and the social networks of Australia's elite suburbs. Urban Geography, 1-22. 
Mosman is a state suburb in Sydney, New South Wales, significantly larger than Toorak with a population of 27,452 recorded in the 2011 Census. Located 8km north east of the Sydney CBD (Figure 3), it is also famous for its Balmoral Beach and spectacular views of the Sydney Harbour. The capital gains declared by residents in Mosman's postcode in $2014-5$ - over $\$ 460,000,000$ - were second only to the suburb of Vaucluse (postcode 2030) in Sydney, albeit by a very large margin and inflated by a relatively large population (Australian Tax Office, 2015).

Figure 3: Mosman and Greater Sydney

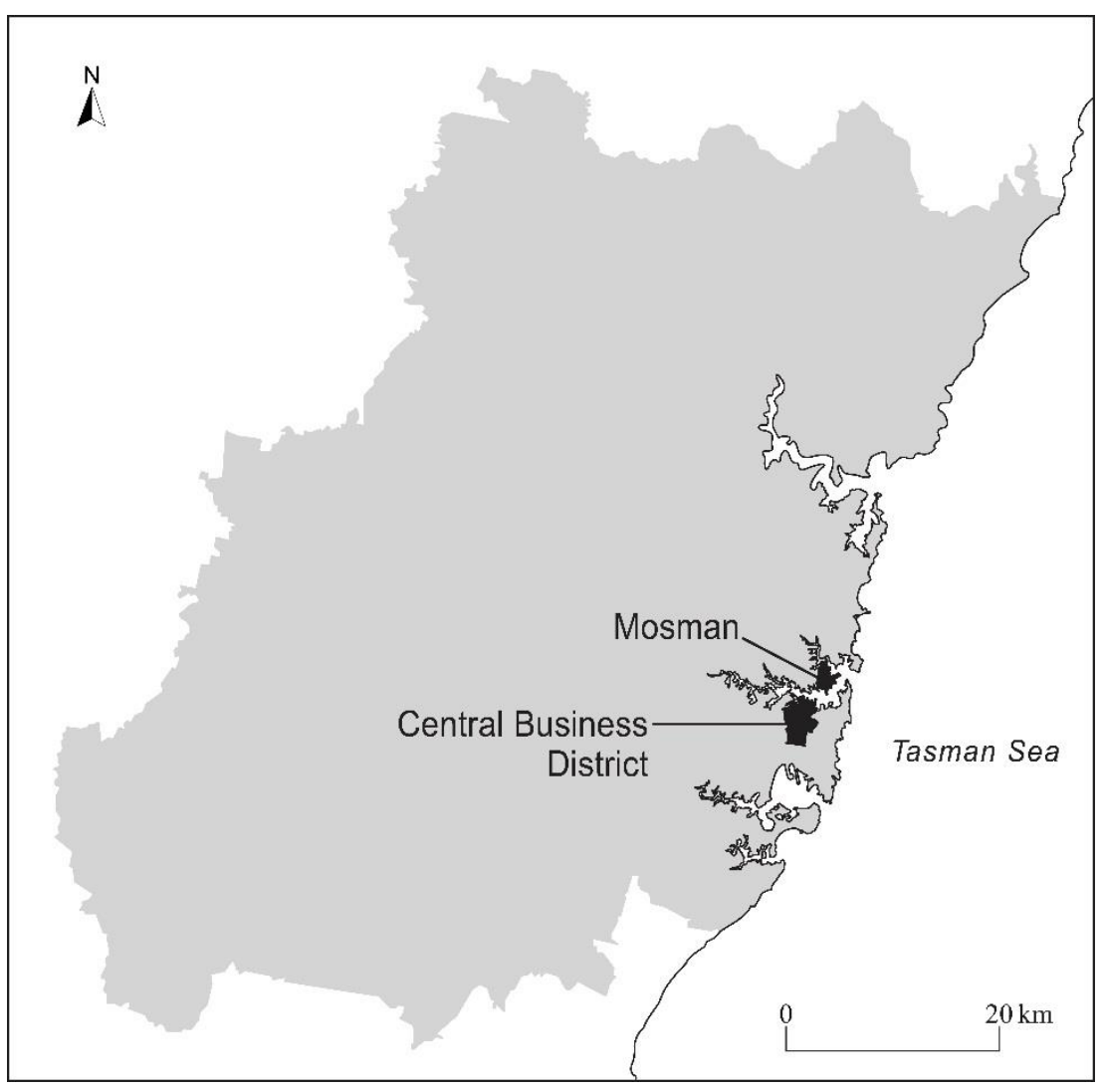

Credit: Chandra Jayasuria

Cottesloe is a state suburb in Western Australia, $11 \mathrm{~km}$ west of Perth CBD (Figure 4). With one of Perth's most popular beaches, the suburb is also famous for the Norfolk Pine trees decorating its main streets. In 2009, at the height of Western Australia's mining boom, houses in Cottesloe were the most expensive in Australia (followed by Mosman). Yet, while Cottesloe's affluence is notable, it is of a lower rank compared 
to Toorak and Mosman's wealth. In 2014-15, Cottesloe's postcode ranked fourth in Western Australia, and 57th in Australia in capital gains recorded by the Australian Tax Office (2015).

Figure 4: Cottesloe and Greater Perth

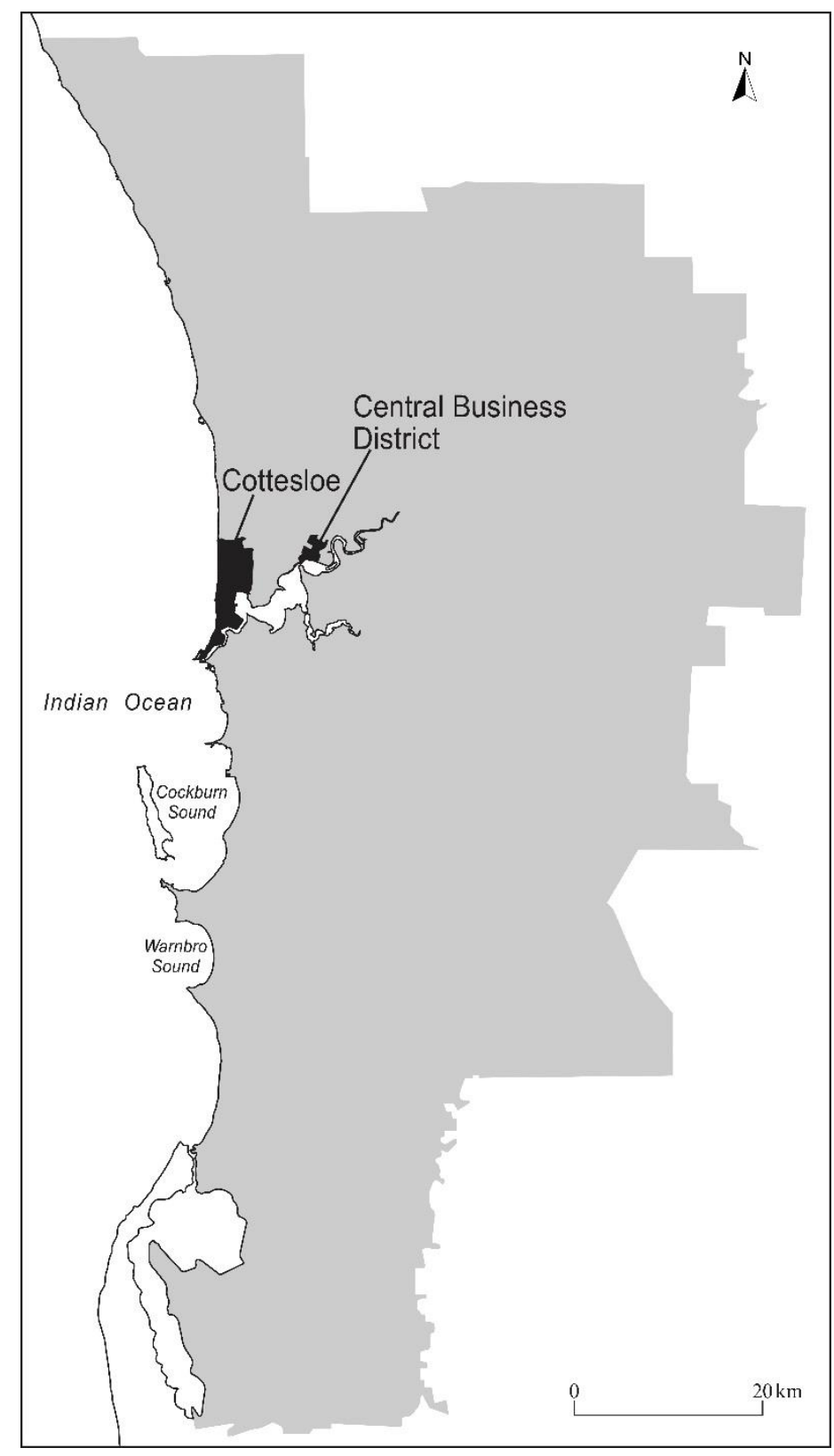

Credit: Chandra Jayasuria

Accepted version of Wiesel, I. (2018). Distinction, cohesion and the social networks of Australia's elite suburbs. Urban Geography, 1-22. 
Reflecting their central metropolitan location, both Toorak and Mosman are relatively dense suburbs in Australian terms, with approximately $48-49 \%$ of their housing stock being apartments, compared to Cottesloe (19\%) and the national average (13.6\%). The three suburbs include a relatively high proportion of renters, 31-34\%, compared to the national rate of $29 \%$ (ABS, 2011).

\section{Methods}

A mixed-method approach was utilised in this study, to better represent both the lived experience and the generalizable causal mechanisms of neighbourhood social networking (van Ham et al., 2012: 5). A self-completion questionnaire was distributed in 2015 to approximately 12,600 letterboxes in Mosman, Toorak and Cottesloe. This included all addresses covered by Australia Post's letterbox drop service in these suburbs.

The survey targeted adults aged 18 years or older. The questionnaires included questions about residents' involvement in local development matters, their life style activities in and outside the neighbourhood, their social networks and their demographic characteristics.

The overall response rate for the questionnaire survey was $11.90 \%$, and 1,090 of the questionnaire response completed the full survey. Although the educational attainment levels of respondents were higher than average, the sample was overall representative of the population in the three selected suburbs in relation to most other measured variables, including household income (see Table 2).

Using the questionnaire as a recruitment tool, 46 residents of the three suburbs participated in follow-up, in-depth face-to-face interviews. Participants selected were those identified as possessing relatively high wealth or senior institutional positions. Others were included too if, based on their survey responses, they were identified as either well connected in elite social circles (i.e. having friends in high status occupations) or more actively involved in local urban planning affairs.

Most interview participants were Australian born. The sample was skewed towards older participants (18 over 65 years old, 20 between 45-64, 6 between 30-44, and 2 
between 18-29), reflecting the relatively older age profile of the suburbs but also higher interest and availability among retired residents to participate in an interview. The number of interviews undertaken in Mosman (23) was about twice as high as Cottesloe (11) and Toorak (12), mirroring the difference in the suburbs' population. 26 participants were male and 20 female.

Table 2: Survey sample, key characteristics

\begin{tabular}{|c|c|c|c|c|}
\hline & \multicolumn{4}{|c|}{ Questionnaire respondents } \\
\hline & $\begin{array}{l}\text { Mosman } \\
(n=588)\end{array}$ & $\begin{array}{l}\text { Toorak } \\
(n=365)\end{array}$ & $\begin{array}{l}\text { Cottesloe } \\
(n=137)\end{array}$ & $\begin{array}{l}\text { Total } \\
(\mathrm{n} \\
1090)\end{array}=$ \\
\hline \multicolumn{5}{|l|}{ Gender, $n$} \\
\hline Male & 210 & 162 & 61 & 433 \\
\hline Female & 368 & 200 & 72 & 640 \\
\hline Age, median ( $\min , \max$ ) & $\begin{array}{r}58(19, \\
97)\end{array}$ & $\begin{array}{r}60(21 \\
96)\end{array}$ & $\begin{array}{r}59(22, \\
91)\end{array}$ & $\begin{array}{r}58(19, \\
97)\end{array}$ \\
\hline \multicolumn{5}{|l|}{ Place of born, $n$} \\
\hline Born in Australia & 368 & 266 & 88 & 722 \\
\hline Born elsewhere & 220 & 99 & 49 & 368 \\
\hline \multicolumn{5}{|l|}{$\begin{array}{l}\text { Educational attainment, } \\
n\end{array}$} \\
\hline $\begin{array}{l}\text { High school } \\
\text { graduate } \\
\text { Professional }\end{array}$ & 43 & 37 & 5 & 85 \\
\hline $\begin{array}{l}\text { certificate or } \\
\text { diploma }\end{array}$ & 114 & 54 & 22 & 190 \\
\hline $\begin{array}{l}\text { Undergraduate } \\
\text { degree }\end{array}$ & 198 & 108 & 47 & 353 \\
\hline $\begin{array}{l}\text { Postgraduate } \\
\text { degree }\end{array}$ & 198 & 149 & 52 & 399 \\
\hline \multicolumn{5}{|l|}{$\begin{array}{l}\text { Household income, } \\
\$ \text { per annum }\end{array}$} \\
\hline Under $\$ 99,999$ & 126 & 61 & 30 & 217 \\
\hline$\$ 100,000-\$ 199,999$ & 125 & 80 & 31 & 236 \\
\hline$\$ 200,000-\$ 499,999$ & 126 & 71 & 38 & 235 \\
\hline$>\$ 500,000$ & 73 & 37 & 12 & 122 \\
\hline $\begin{array}{l}\text { Do not wish to } \\
\text { disclose }\end{array}$ & 138 & 116 & 26 & 280 \\
\hline \multicolumn{5}{|l|}{ No of bedrooms, $n$} \\
\hline$\leq 2$ & 197 & 141 & 17 & 355 \\
\hline 3 & 153 & 117 & 54 & 324 \\
\hline 4 or 5 & 202 & 89 & 60 & 351 \\
\hline$>5$ & 13 & 10 & 4 & 27 \\
\hline \multicolumn{5}{|l|}{$\begin{array}{l}\text { How long have you } \\
\text { lived in, } y r\end{array}$} \\
\hline Less than a year & 47 & 25 & 5 & 77 \\
\hline $1-4$ years & 103 & 76 & 18 & 197 \\
\hline $5-10$ years & 90 & 52 & 14 & 156 \\
\hline $11-20$ years & 118 & 85 & 33 & 236 \\
\hline over 20 years & 223 & 122 & 66 & 411 \\
\hline Working status, $n$ & & & & \\
\hline
\end{tabular}

Accepted version of Wiesel, I. (2018). Distinction, cohesion and the social networks of Australia's elite suburbs. Urban Geography, 1-22. 
$\begin{array}{llll}\text { Working full-time } & 209 & 132 & 39\end{array}$

$\begin{array}{lllll}\text { Working part-time } & 134 & 91 & 40 & 265\end{array}$

Not in paid

employment*

245

142

$58 \quad 445$

Note: ${ }^{*}$ including people in retirement or in unemployment

The interviews were typically one hour long each, either in participants' home or a nearby café (and in one memorable case a participant's boat in Sydney Harbour). The interviews were semi-structured around the following broad themes: residents' perceptions of their neighbourhood's status, character and lifestyle; their social networks within and outside the neighbourhood; and, their involvement in local planning, development and transport issues. The qualitative data obtained in these interviews - specifically those data that pertain to interviewees' social networks - is the core of the analysis presented in the rest of the paper. The real names of all research participants have been replaced with pseudonyms, with minimal additional personal information, to protect their anonymity and privacy.

The statistical data obtained from the questionnaire plays a secondary role in this paper, and more comprehensive analysis of survey results will be reported elsewhere. Selected quantitative data is presented in the next section, describing the composition of social networks in the three suburbs, and extracting key socioeconomic and behavioural factors associated with acquisition of higher status networks. This serves as context for the rest of the empirical sections which focus on qualitative analysis of mechanisms through which elite suburb residents assemble their social networks.

\section{High powered networks}

Studies of neighbourhood social capital typically involve measuring social networks in terms of their size, spatial dispersion, density, durability, reciprocity, trust and the social status of members (Stone, 2001; Lin et al., 2001). Respondents were provided a long list of occupations, and were asked to tick a box if they had a friend in each occupation. It was explained that, for the purpose of the questionnaire, a 'friend' is defined as someone who they consider a friend, and whom they meet outside of work at least several times a year. It was not necessarily someone who lives in their local neighbourhood. 
The results highlighted the high status of members in the social networks of three neighbourhoods' residents (Table 3). In Toorak and Cottesloe, for example, about one in seven survey respondents $-15 \%$ and $13 \%$ respectively - reported having a friend who is a Member of Parliament. Across the three suburbs, more than $70 \%$ had a friend who is an owner of a business, and close to half had a friend who is a Chief Executive Officer or General Manager of a company.

While a substantial proportion of respondents had a friend who is a manual worker, their networks mostly included professionals in more high-status occupations such as medical practitioners, legal professionals, artists and finance or business professionals. Lower income and lower status occupations were more weakly represented in residents' networks across the three suburbs.

Table 3: Friends in social networks of elite suburb residents by occupational status

\begin{tabular}{lrrr}
\hline Respondents with a friend who is a... & & & \\
& Mosman $(\mathbf{n}=\mathbf{5 8 8})$ & Toorak $(\mathbf{n}=\mathbf{3 6 5})$ & Cottesloe $(\mathbf{n}=\mathbf{1 3 7})$ \\
Upper class occupations, \% & & & \\
$\quad$ Member of Parliament & 5.95 & 15.07 & 13.14 \\
Owner of business & 70.41 & 76.71 & 75.18 \\
Chief executive or general manager & 47.45 & 47.12 & 49.64 \\
Senior public servant & 11.90 & 13.15 & 21.90 \\
Professionals, \% & & & \\
Tertiary education teacher & 31.46 & 38.63 & 43.07 \\
Engineer & 37.93 & 38.63 & 57.66 \\
School teacher & 48.64 & 45.75 & 66.42 \\
Medical practitioner & 52.21 & 61.64 & 65.69 \\
Legal professional & 50.17 & 49.04 & 48.18 \\
ICT professional & 38.95 & 31.23 & 33.58 \\
Business professional & 71.77 & 67.12 & 63.50 \\
Artist & 35.54 & 38.08 & 41.61 \\
Public servant & 28.57 & 24.38 & 42.34 \\
Nursing professional & 33.84 & 35.89 & 54.01 \\
Working class occupations, \% & & & \\
Community \& personal service worker & 35.37 & 33.42 & 35.77 \\
Clerical \& administrative worker & 34.01 & 28.49 & 40.15 \\
Technicians and trades worker & 26.36 & 20.00 & 32.85 \\
Sales worker & 32.48 & 27.95 & 27.74 \\
Machinery operator or driver & 29.42 & 31.51 & 46.72 \\
Manual worker & 10.88 & 6.85 & 6.57 \\
\hline \hline
\end{tabular}

Source: Author's survey

Accepted version of Wiesel, I. (2018). Distinction, cohesion and the social networks of Australia's elite suburbs. Urban Geography, 1-22. https://www.tandfonline.com/doi/abs/10.1080/02723638.2018.1500250 
Yet, access to high-powered social networks was unevenly distributed within each of the suburbs. An ordinal logistic regression analysis found, for example, that high socioeconomic status, high levels of local involvement, and higher levels of participation in 'high-brow' cultural activities (in particular theatre, classical concerts and art collection) were each associated with high-powered social networks (i.e. having friends in high status occupations) (Wiesel, forthcoming).

The social networks of survey respondents were not restricted to the neighbourhood. However, length of time lived in the neighbourhood was positively correlated with an increase in the number of one's high-status friends and a decrease in low-status friends. Controlling for age and socioeconomic status, people who lived in their neighbourhood longer than 10 years had a higher number of connections in highstatus occupations (mean $=2.26$ ) than those who lived in their neighbourhood less than 10 years (mean $=1.76, t=-2.81, p=.006$ ). In Toorak, the correlation between length of residency and high-powered network was only significant for male babyboomers (Wiesel, forthcoming). These data are indicative of the role of the neighbourhood in the formation of elite networks.

The qualitative data presented in the following sections deepens the understanding of these processes. The data is structured in four sections focused on different institutions and practices through which social connections in the neighbourhood (and beyond it) are initiated and maintained.

\section{The neighbourhood as a social institution: warm 'villages' and 'cold environments'}

Geographic proximity in the neighbourhood creates opportunities for occasional unplanned encounters between residents and their immediate and more distant neighbours. These encounters can develop over time into acquaintanceships or friendships of different sorts, but also conflict or detachment. In elite neighbourhoods, the nature of such encounters and social relations is mediated by practices of distinction (Bourdieu, 1986), although these can vary significantly across different elite neighbourhoods, as evident in Cottesloe, Mosman and Toorak. 
In Cottesloe, more intimate relationships of friendship and mutual support were described as an important aspect of the neighbourhood's social character. These were relatively dense networks in the sense that "everyone knows everyone", as one participant commented by way of exaggeration.

Relatively close relations with neighbours in Cottesloe were described by some residents as distinctive to other suburbs:

I've certainly got to know my neighbours here probably better than I have in other places that l've lived before, yeah. (Dave, Cottesloe)

One explanation for Cottesloe's denser networks is the smaller population of the neighbourhood. Additionally, interview data highlighted that these networks were also the outcome of proactive community building efforts by some residents. These informal community activists initiated events such as street parties and welcome drinks for newcomers to facilitate contact and friendship between neighbours.

While producing a sense of belonging and connectedness for some, these tight neighbourhly relations were exclusionary in some respects, as a form of distinction. The lack of anonymity meant outsiders were more easily identified, pointed out and excluded. One Cottesloe resident, for example, noted that a stranger that 'doesn't belong' in a street is likely to get noticed by local residents:

Even if there's a loud car going down the street, that doesn't belong here... that sounds a bit snooty I know but ... I'll look up, what's going on. (Catherine, Cottesloe)

In Mosman, friendships between direct neighbours were also common, although unlike Cottesloe, they did not always evolve into dense networks across whole streets, let alone the whole suburb. Friendships with neighbours were valued as a useful resource in residents' everyday life and even in their business careers (as I elaborate in the penultimate section), in terms that resembles Putnam's (2000) conception of social capital as connectedness: 
It's not extensive but we have a lovely network. That - it extends to things like the simple things in life of childminding, collecting letters when you're away on holidays, babysitting when needed, putting rubbish out if neighbours are [away]. (John, Mosman)

Alongside friendships and reciprocity between neighbours, fraught neighbourly relations were also common in Mosman, more so than Cottesloe and Toorak. Tensions and conflicts were often triggered by disputes surrounding residential development (e.g. renovations and extensions to existing dwellings) as well as trees blocking Sydney harbour views. Such disputes can be interpreted as reflecting a tension between different personal and collective practices of distinction: the protection of harbour views from private homes; the development of supersized mansions; and, the maintenance of a neat and leafy suburban environment.

Conflicts among neighbours are not exclusive to elite neighbourhoods, although a study in the Netherlands by Nieuwenhuis et al. (2013) found that such conflicts are more common in relatively affluent neighbourhoods. It is possible that the high economic and cultural capital that is attached to property and views, raises the stakes and tensions leading to such conflicts in elite neighbourhoods.

Although common, neither close friendly relations between neighbours, nor neighbour conflicts, were presented by interviewees as the defining features of Mosman's social character. Rather, participants in the study emphasised more fleeting encounters and looser acquaintanceships with other residents, not necessarily immediate neighbours, and often recognised only by face. The experience of bumping into familiar faces in the neighbourhood while walking, shopping, going to cafes or the beach, was described as a quintessential Mosman experience, and an important element of residents' sense of belonging in the suburb:

You don't always know names but frequenting either the shops up here or frequenting the beach or Frenchy's [local café], you come across the same people all the time. So there's an element of comfort in I guess just the familiarity that comes with community. (Scott, Mosman) 
Both fleeting encounters with neighbourhood acquaintances in Mosman, and more dense networks of friendship in Cottesloe, were described by research participants in terms of a 'village' culture. Interviewees' 'village' discourse can be interpreted as a practice of distinction, a way of distinguishing their own suburb from the rest of the city in which it is located.

Residents of Mosman and Cottesloe linked the 'village' social characteristics of their suburb to its physical features and administrative structures. When mobilising against proposals for amalgamation with other local councils or against residential densification, residents of the two suburbs claimed they were fighting to preserve their village character. The village was perceived, at once, as a neighbourhood attribute that residents actively defended from external threats; and, a source of power (social capital) mobilised in such campaigns. In turn, campaigns to defend their village from external threats, were important opportunities for social networking reinforcing the sense of a village, as evident in John's narrative below:

I was part of a residents group that objected to [a commercial development proposal in a Mosman residential street]... In terms of rounding up the interest of surrounding neighbours and you know, sort of got some funding to do what we did [campaigning against the development]. A small amount of money but you actually created a very strong social cohesion. We organised street parties. ...We were introducing people together - we were introducing people that lived in the region for more than 30 years and never met. Those street parties, you know, well we're talking about 15 years on, still [go on]...(John, Mosman)

Both in Mosman and in Cottesloe, participants pointed to certain groups within their suburb - especially those referred to as 'new money' - who did not participate in the 'village' rituals of either fleeting contact (Mosman) or more dense and enduring networks of friendship among neighbours in the same street (Cottesloe). Rather, these residents were described as performing alternative practices of distinction through detachment: 
I'm not saying everybody, but there's a high percentage that don't want to go 'morning' or whatever ... I think maybe it's a new money thing. These people are making money and they've got this idea above their station (Brian, Cottesloe)

I think that maybe that's the question of demographics of the community of Mosman that they keep to themselves, they feel - they don't feel a need to be part of the community. They're quite happy to sit in their own luxurious homes and look at the harbour views. (Ian, Mosman)

Whereas in Mosman and Cottesloe such practices of detachment were secondary to the more dominant 'village' rituals, in Toorak detachment and alienation were described as the dominant practice defining the suburb's social character:

No-one in Toorak talks to anybody else ... In [previous suburb I lived in] I would know everyone on the street. [In Toorak] people walking past don't even say hello. It's a very cold environment, snobby. Toorak, Toorak-ish, you could say. (Mark, Toorak)

Despite the "snobby" environment described by Mark above, interviewees in Toorak maintained social connections with other residents in their street or neighbourhood. Such networks were often initiated as part of campaigns against development proposals, or through participation in neighbourhood institutions such as sports clubs and schools, as elaborated in the following section.

\section{Networking in neighbourhood sports clubs}

Much of the networking - or social capital building - of a neighbourhood occurs in institutions such as schools, sports clubs and formal associations (Putnum, 2000; Nast and Blokland, 2014). Romig's (2010) analysis of social capital in an affluent Phoenix neighbourhood, highlights the importance of social institutions such as church, special interest clubs (e.g. sports, books and wine tasting clubs) and neighbourhood cafes. Participation in such institutions facilitated a 
general sense of community and belonging, as well as accumulation of both bonding and bridging social capital. Similarly, in my study, neighbourhood institutions such as schools and sports clubs were described by interviewees as instrumental in the process of building their social networks and capital.

Research participants associated much of the socialising in their neighbourhoods to sports clubs and activities. Many residents of Mosman, Cottesloe and Toorak are enthusiastic participants in a wide variety of sports. For participants of all age groups, genders and income levels in the three suburbs, sport was integral to weekly, if not daily, routines. Indeed, a recent Australian study found self-reported physical activity was highest in the most affluent urban areas of Australia, with Cottesloe and Toorak ranking first and Mosman seventh of all suburbs in their respective cities (AHPC, 2017).

Participation in sports was described as an opportunity for socialising, from chit-chat to organised social events before, during or after the physical activity. Some participants developed meaningful friendships with people they met through sports. These ties were described as important in terms of both connectedness and distinction:

In my family there used to be this story or joke about you're well-set in life if you have a friend who is a lawyer, who is a doctor, and I don't know the third. There was a third thing....I've got all those covered ... through soccer, because there's lawyers, there's judges that play football (Brian, Cottesloe)

Certain sports were notable for facilitating a more inclusive sense of connectedness across social differences such as age, gender and wealth (e.g. between super-rich and 'merely-rich' residents). For example, several participants noted the inclusivity of swimming groups in Mosman and Cottesloe's beaches:

They've all become friends just because they swim and so it's a very eclectic mix in an enormous range of skills, money, experiences, ages... and you mix with their group of friends. (Lisa, Mosman) 
There's a group of people that go swimming very early in the morning ranging in age from young women in their 20 s right through to ... a lovely friend of mine, who's 99. ... It's lovely having that intergenerational connection (Shelly, Cottesloe)

In contrast, in Toorak, tennis in residents' private courts, were associated with more exclusive social cliques. In Mosman and Cottesloe, sailing was another more exclusive sports activity because of the high cost of participating (owning a boat). However, less affluent but well-connected residents were also able participate as crew members on someone else's boat.

Particularly in Mosman, the status of a high-achieving athlete held high currency as cultural capital and facilitated access to extensive social networks:

So what holds the community together - for us it's that sporting connection. .... We've made our own quite tight group of people. Because my girls were quite successful in [competitive sports activity], everybody knows my eldest daughter.... (Norah, Mosman)

Sports clubs were described by several participants as large and powerful institutions in these suburbs as well as central hubs for social networking. Many members join such clubs purely for the social side. Tennis clubs, in particular, attracted members who never play tennis but enjoy the facilities for socialising with other club members. Membership as directors on the board of a local sports club was not only a status symbol, but also an entry point into elite social networks:

l've certainly made some connections through it [serving on board of local sports club], on a business level as well as some very good friendships ... some of them have high level business positions, and when they develop respect for you, if they need to appoint a new director to one of their own corporate boards, they offer it to you. So it did help in that sense. (Daryl, Mosman) 
As noted by Connell et al. (1982: 154), the social institutions underpinning elite integration walk a fine line between two opposing objectives: to draw lines and stress social distinction, on the one hand; and to avoid a politically damaging reputation for privilege and exclusion, on the other hand. This tension perhaps explains the rise of sport clubs as central social hubs in Australian elite suburbs. Although some of these sports (such as Australian Rules Football) are perceived as non-elitist, all-Australian sports, they nonetheless allow distinction through allegiance to the exclusive local sports club in which elite suburb residents invest significant time, money and sweat. The competitive nature of these sports is well aligned with the capitalist values held dear in these neighbourhoods.

\section{Schools as social hubs for children and parents}

Schools within, or in close proximity to, elite suburbs are another important hub of socialising, for both children and their parents. In Australia, this is not unique to elite suburbs, with previous research indicating that schools play a role as catalysts of social connections in neighbourhoods for both children and parents (Wood et al., 2013). However, Hill et al. (2014), comparing social relations in one affluent and one deprived neighbourhood in England, observed social interaction between residents was generally higher in the poorer neighbourhood, except for social interaction between parents collecting children from school which was greater in the affluent neighbourhood. In the Australian context, Connell et al. (1982: 148) commented that:

The ruling-class school is a focus in a dense and extensive network of relationships. Far more than with the working-class school, it is the shared space of parents, teachers and students.

More recent work by Kenway (2017) highlights the accumulation of institutionalised cultural capital in Australian elite schools. Kenway focuses on transnational students attending Australian elite schools as a strategy for accumulation of institutional credentials. She compares these deliberate, conscious strategies of cultural capital accumulation by international students, to those of native students, where such accumulation is unconscious and naturalised, unremarked and unremarkable. 
More than three decades after Connell et al.'s observation, my study revealed private schools continue to serve a similar function for the Australian elite.

Children's school were one of the most important hubs where parents built their own social network of friends. These networks were not necessarily confined to the boundaries of the suburb, but to a slightly wider metropolitan subregion. For many, close friendships formed between parents during children's school age, were sustained long after the children have left school.

I think the schools have displaced that community collective thing that the churches used to have - I reckon. Now there's so much parent involvement in the schools, that's where the community kind of - that's where the cohesion happens, is around the schools (Vicky, Mosman)

Most of those long-term friends that we made, and some still are good friends, they tended to be when our children were at primary school rather than senior school... we still have good friends who we've known for 25 years because our children were at primary school, the little ones. (Barbara, Toorak)

These findings echo Holmqvist's (2017, p. 24) observations in Stockholm, as well as Kenway's (2017, p.41-42) findings on the importance of Australian elite schools as hubs of socialising for parents. However, while Kenway describes the friendships formed between parents as fleeting, my findings point to more sustained relationships.

Schools are also a site for socialising between children, and the relationships formed during school days remain part of their social networks as adults. Several participants noted the connections with some of Australia's most prominent businessmen and politicians formed during their own or their children's school years. Participants noted that such networking opportunities were an important motivation to send children to elite private schools, but were also at times apologetic about the exclusiveness of these networks: 
Networks are still really, really important and, yes, totally living in Toorak and the schools that you send your children to. The school the boys are at, Ted Baillieu's son was there while he was Premier of Victoria ... I would frown on my kids enormously if they chose their friends [based on] schools or educations or opportunities given to them and parents ... But I think networks are really important and we all like to give our children the advantages we can. (Danielle, Toorak)

Some participants, who did not have children going to local schools, felt excluded and a difficulty to penetrate the social networks that schools facilitated.

I think you'd probably find the answer would be different if we had kids, but because we are both professionals we don't really have that big network of people in the local area yet. We don't have a connection to a local school or a day care centre. (Eleanor, Mosman)

Perth is very much based on where did you go to school sort of thing, and those cliques sort of exist, really. So it's very hard, as an outsider, to come in and penetrate that in a way (Brian, Cottesloe)

\section{Convergence of external and neighbourhood networks}

Elite networks are not confined to the residential neighbourhood (Atkinson, 2008), yet the neighbourhood - as a space of proximity and encounter, as a set of institutions and as an institution in its own right - considerably influences their form and both their exchange and relational contents (Williams, 2007). In this sense, neighbourhoods should be understood not as 'containers' of social networks (Blokland and Savage, 2008: 8), rather as focal points where different networks converge. This point was exemplified in the convergence of neighbourly and professional relations in the three suburbs.

In Mosman and Toorak, for example, residents noted the relative high concentration of people working in the financial sector as well as lawyers and judges. The 2016 Census revealed Mosman is "Sydney's biggest lawyer huddle" (Wade, 2018), with 
close to 600 lawyers in residence. It was also the second most popular suburb for managers (3360 residents) and third most popular suburb for doctors (307 residents) in Sydney. Consequently, some residents were connected through both professional and neighbourhood networks, and such convergence appeared to strengthen both types of networks:

Some friends have come because of our proximity, so neighbours ... Most of them had some sort of work connection... With your immediate neighbours, yes, l've had business contacts and work opportunities through my immediate neighbours. (John, Mosman)

The people that I'm closest to at work that I get a friendship with I guess, they are the people who live in the locality as well ...probably all of them would be in Mosman. The people who don't live in Mosman we seem to lose touch with (Norah, Mosman)

We've picked up the odd - yes the odd business client scenario from informal catch ups that emanated originally from - yeah meeting [in Cottesloe]... because of proximity to some of the people that we deal with (Rob, Cottesloe)

One notable example was mentioned by several residents in Mosman. A group of residents working in the $\mathrm{CBD}$, including some in senior positions within the finance industry, are known to socialise regularly during their morning ferry commute to the city:

Like when my husband goes on the ferry from Taronga Zoo sometimes to the city, so there's a group of people .... When you're on that ferry it is actually a powerful place ... they're all going to work at the same time. They get actually quite friendly socially. My husband ... is still friends with these people and they all went out to the cinema the other day. But these people are like scarily high up in various businesses... the banks and things, the financial services and things and they are the real like the high flyers in those businesses. (Norah, Mosman) 
Some participants emphasised their choice to keep their social networks and professional or business networks separated. Yet, their depiction of these choices as a conscious effort, only served to highlight the ease through which professional and social networks converge in the elite neighbourhood, in mutually constitutive ways.

\section{Discussion}

Elites secure their advantage not only in the boardrooms of the corporate world and the corridors of government, but also through fleeting encounters with familiar faces in their neighbourhood café, or more intensive networking with immediate neighbours, with other members of the local sports club or with other parents in their children's school. As such, elite neighbourhoods are more than just fortified playgrounds for the conspicuous spending of economic capital. Rather, they should be recognised as spaces and institutions in which capital is being produced and accumulated in its varied social, cultural and economic guises (Bourdieu, 1986; Holmsqvist, 2017).

In this paper I have focused on the elite neighbourhood's role in the accumulation of social capital. While my findings affirm that neighbourhood contacts are but a small part of the wider social and professional networks of elites (Atkinson, 2008), they also demonstrate the importance of the neighbourhood as a focal point for convergence of diverse networks: local and distant, personal and professional, formal and informal (see also Romig, 2010). The neighbourhood creates opportunities for encounter and friendship between residents, both as a site in which social institutions such as schools and sports clubs are located, or could be easily accessed from; and, as a social institution in its own right, with distinctive norms and expectations about social relations between residents.

The social networks of elite neighbourhoods serve as sources of elite power, in two primary ways that correspond with both Putnam's conception of social capital as connectedness, and its conception by Bourdieu as a practice of distinction.

First, social connections bridging across diverse elite circles co-residing in the neighbourhood can be understood a mechanism of elite integration, and as such a source of elite power. As evident in the questionnaire analysis, the social networks of 
many elite suburb residents are composed of friends in senior positions across political, economic and cultural domains. This suggests a degree of cohesion, or integration, in the elite, that can be attributed at least partly to socialising that takes place in the neighbourhood. As discussed by Wiesel and Levin (2017) elite neighbourhoods' networks - especially in Mosman and Toorak - are still stratified and fragmented to a degree, particularly along lines of wealth (new money networks separate from old money; super-rich separated from the merely-rich) and ethnicity (Anglo-Australian networks separate from the Chinese). Nevertheless, co-residence in elite neighbourhoods facilitates a certain degree of cohesion across these dividing lines, through shared interests in relation to the neighbourhood itself, shared participation in some neighbourhood institutions, and overlapping social connections.

Second, elite suburb residency facilitates access to networks of high distinction and power, while securing social distance from the networks of those who are less powerful. The high-powered nature of elite neighbourhood networks was evident in the survey findings: one in seven survey respondents in Toorak and Cottesloe reported having a friend who is a Member of Parliament, indicating direct access to powerful leaders of the state; most participants in the three suburbs also had a friend who is an owner of a business, and close to half were friends with a CEO of a company. In addition to direct informal access to material resources, these social networks are also part of the lifestyle offerings of elite neighbourhoods, which produce distinction (Bourdieu, 1986) or the consecration effect (Holmsqvist, 2017).

There is no single form of socialising that could be distinguished as characterising elite neighbourhoods. On the contrary, social relations in Cottesloe, Mosman and Toorak are characterised by different forms and practices: from dense networks of friendship (Cottesloe), through to fleeting acquaintances performed through unplanned occasional encounters (Mosman), and a sense of detachment (Toorak). And yet, in its varied manifestations, and its varied conceptions (as distinction and as connectedness), social capital building in elite neighbourhoods should be recognised as an important aspect of rising national and global inequalities (Piketty et al., 2014; Credit Swiss, 2016; ABS, 2015). 


\section{References}

Aldrich, Daniel (2012). Building resilience: Social capital in post-disaster recovery.

Chicago: University of Chicago Press.

Atkinson, Rowland (2008). The flowing enclave and the misanthropy of networked affluence. In: Talja Blokland \& Mike Savage (eds) Networked urbanism: social capital in the city. Hampshire: Ashgate, pp. 41-58.

Atkinson, Rowland (2016). Limited exposure: Social concealment, mobility and engagement with public space by the super-rich in London. Environment and Planning A 48(7), pp. 1302-1317.

Australian Bureau of Statistics (ABS) (2011). Community Profiles (http://www.abs.gov.au/websitedbs/censushome.nsf/home/communityprofiles) (accessed 8 May 2017).

Australian Bureau of Statistics (ABS) (2015). Household income and Wealth, Australia, 2013-14,

http://www.abs.gov.au/AUSSTATS/abs@.nsf/DetailsPage/6523.0201314?OpenDocument (accessed 8 June 2017).

Australian Health Policy Collaboration (AHPC) (2017). Australia's Health Tracker by Area (http://www.atlasesaustralia.com.au/ahpc/atlas/atlas.html?indicator=i18) (accessed 8 May 2017).

Australian Tax Office (2015) Taxation Statistics 2014-15, Table 6, accessed 16 Feb 2018, https://data.gov.au/dataset/taxation-statistics-2014-15

Blokland, Talja \& Savage, Mike (2008) Social capital and networked urbanism. In: Talja Blokland \& Mike Savage (eds) Networked urbanism: social capital in the city. Hampshire: Ashgate, pp. 1-22.

Bourdieu, Pierre (1986). The forms of capital. In: Richardson J G (ed) Handbook of Theory and Research for the Sociology of Education. New York: Greenwood Press, pp. 241-258. 
Butler, Tim (2008). Social capital and the formation of London's middle classes. In: Talja Blokland \& Mike Savage (eds) Networked urbanism: social capital in the city. Hampshire: Ashgate, pp. 217-236.

Campbell, Ernest (1963) The 60 Rich Families Who Own Australia. Sydney: Current Book Distributors.

Caneva, Lina (2015). Connected communities: How Australia's social capital has declined, https://probonoaustralia.com.au/news/2015/08/connected-communitieshow-australias-social-capital-has-declined/

Connell, Raewyn, Ashenden, Dean \& Kessler, Sandra (1982). Making the difference: Schools, families and social division. Sydney: Allen \& Unwin.

Cousin, Bruno \& Chauvin, Sebastien (2017). Old money, networks and distinction: The social and service clubs of Milan's upper classes. In: Ray Forrest, Sin Yee Koh \& Bart Wissink (eds) Cities and the super-rich: Real estate, elite practices and urban political economies, New York: Palgrave, pp. 253-272.

Credit Swiss (2016) Global Wealth Report https://www.creditsuisse.com/au/en/about-us/research/research-institute/global-wealth-report.html (Accessed 22 June 2017)

Cunningham, Niall (2017). Making and mapping Britain's "new ordinary elite", Urban Geography, DOI: 10.1080/02723638.2017.1390721

Dorling, Danny (2012). Inequality constitutes a particular place, Social and Cultural Geography, 13(1), pp. 1-10.

Forrest, Ray and Kearns, Ade (2001). Social cohesion, social capital and the neighbourhood. Urban studies 38(12): 2125-2143.

Frantz, Klaus (2006). Private gated neighbourhoods: a progressive trend in US urban development. in: Georg Glasze, Chris Webster and Klaus Frantz (eds) Private cities: Global and local perspectives. London: Routledge, pp. 64-75.

Galster, George (2012). The mechanism (s) of neighbourhood effects: Theory, evidence, and policy implications. in: Maarten Van Ham, David Manley, Nick Bailey, 
Ludi Simpson, and Duncan Maclennan (eds) Neighbourhood effects research: New perspectives. Netherlands: Springer, pp. 23-56.

Gauntlett, David (2011). Three approaches to social capital. Available at: http://www.makingisconnecting.org/gauntlett2011-extract-sc.pdf (accessed 22 June 2017)

Gilding, Michael (2004). Secrets of the super rich. Pymble: HarperCollins.

Gomez, Rafael \& Santor, Eric (2001). Membership has its privileges: The effect of social capital and neighbourhood characteristics on the earnings of microfinance borrowers. Canadian Journal of Economics, 34(4): 943-966.

Henning, Cecilia \& Lieberg, Mats (1996). Strong ties or weak ties? Neighbourhood networks in a new perspective. Scandinavian Housing and Planning Research 13(1): 3-26.

Higley, John, Deacon, Desley \& Smart, Don (1979). Elites in Australia. London: Routledge.

Hill, Jessica, Jobling, Ruth, Pollet, Ruth \& Nettle, Daniel (2014). Social capital across urban neighborhoods: A comparison of self-report and observational data. Evolutionary Behavioral Sciences 8(2): 59-69.

Holmqvist, Mikael (2017). Leader communities: The consecration of elites in Djursholm, New York: Columbia University Press.

Israel, Emil \& Frenkel, Amnon (2015). The distribution of capital forms between cities and suburbs and their impact on social justice in space, Urban Geography, 36:4, 578-607, DOI: 10.1080/02723638.2014.982484

Jennings, James (2007a). Social capital, race and the future of inner-city neighbourhoods, in James Jennings (ed) Race, Neighbourhoods, and the misuse of social capital, New York: Springer. pp. 87-108.

Jennings, James (2007b). Introduction, in James Jennings (ed) Race, Neighbourhoods, and the misuse of social capital, New York: Springer. pp.1-6 
Keister, Lisa \& Southgate, Darby (2012). Inequality: a contemporary approach to race, class, and gender. New York: Cambridge University Press.

Kenway, Jane (2017). Travelling with Bourdieu: Elite schools and the cultural logics and limits of global mobility, in: Lisa Adkins, Brosnan Caragh and Steven Threadgold (eds) Bourdieusian Prospects. London: Routledge. Pp 31-48.

Li, Yaojun, Pickles, Andrew \& Savage, Mike (2005). Social capital and social trust in Britain. European Sociological Review, 21(2): 109-123.

Lin, Nan, Fu, Yang-chih \& Hsung, Ray-May (2001). Measurement techniques for investigations of social capital. In: Nan Lin, Karen Cook \& Ronald Burt (eds) Social capital: theory and research. New York: Aldine de Gruyter. Pp. 57-81.

Nast, Julia \& Blokland, Talja (2014). Social mix revisited: Neighbourhood institutions as setting for boundary work and social capital. Sociology, 48(3): 482-499.

Pietsch, Samuel (2004). To have and to hold on to: wealth, power and the capitalist class. In: Rick Kuhn (ed) Class and struggle in Australia. Sydney: Perason Longman, pp. 39-54.

Piketty, Thomas (2014). Capital in the twenty-first century. Cambridge MA: Belknap Press.

Portes, Alejandro (1998). Social capital: Its origins and applications in modern sociology. Annual review of sociology, 24(1): 1-24.

Putnam, Robert (2000). Bowling alone: The collapse and revival of American community. New York: Simon \& Schuster.

Pow, Choon-Piew (2011). Living it up: Super-rich enclave and transnational elite urbanism in Singapore. Geoforum, 42(3) 382-393.

Real Estate Australia (2016a). Melbourne's most expensive suburbs revealed (http://www.realestate.com.au/news/most-expensive-suburbs-in-melbourne/) (accessed 8 May 2017). 
Real Estate Australia (2016b). Western Australia's most expensive suburbs revealed (https://www.therealestateconversation.com.au/2016/07/06/western-australias-mostexpensive-suburbs/1467799099) (accessed 8 May 2017).

Real Estate Australia (2016c). http://www.realestate.com.au/news/most-expensivesuburbs-in-australia-2016/ (http://www.realestate.com.au/news/most-expensivesuburbs-in-australia-2016/) (accessed 8 May 2017).

Romig, Kevin (2010). Community and Social Capital in Upper-Income Neighborhoods: An Investigation in Metropolitan Phoenix, Urban Geography, 31(8), pp. 1065-1079,

Sampson, Robert (2008). Collective efficacy theory: Lessons learned and directions for future inquiry. In: Francis Cullen, John Wright, \& Kristie Blevins (eds) Taking stock: The status of criminological theory, pp.149-164.

Stone, Wendy (2001). Measuring social capital. Canberra: Australian Institute of Family Studies.

Van Ham, Maarten, Manley, David, Bailey, Nick, Simpson, Ludi \& Maclennan, Duncan (2012). Neighbourhood effects research: New perspectives. Netherlands: Springer.

Wade, Matt (2018). Census data reveals the most popular suburbs among occupations, Sydney Morning Herald, 21 January 2018.

Weber, Max (1958). Essays in Sociology. New York: Oxford University press.

Webster, Chris, Georg Glasze, and Klaus Frantz (2002). The global spread of gated communities. Environment and Planning B, 29: 315-320.

Wiesel, I. (Forthcoming). Power, glamour and angst: Inside Australia's elite neighbourhoods. London: Palgrave.

Williams, Russell (2007). Moving beyond vagueness: Social capital, social networks, and economic outcomes, in James Jennings (ed) Race, Neighbourhoods, and the misuse of social capital. New York: Springer. pp. 67-86. 
Wood, Lisa, Giles-Corti, Billie, Zubrick, Stephen \& Bulsara, Max (2013). "Through the Kids... We Connected With Our Community" Children as Catalysts of Social Capital. Environment and Behavior, 45(3): 344-368.

Ziersch, Anna, Baum, Fran, MacDougall, Colin \& Putland, Christine (2005). Neighbourhood life and social capital: the implications for health. Social science \& medicine, 60(1): 71-86.

Zweigenhaft, Richard \& Domhoff, William (2006). Diversity in the power elite: how it happened, why it matters. Lanham: Rowman \& Littlefield. 